mon, which could be readily explained by any one possessing a little elementary knowledge of science.

P. Herbert Carpenter

The Museum, Eton College, June 2I

\section{Intellect in Brutes}

IN NATURE, vol. xx, p. r47, Mr. H. D. Barclay writes:"The fact that a cat or a dog subject their food to examination before eating it, does not, most assuredly, prove the possession of abstract powers of thought in the animal. Mr. Romanes here says :- 'The motive of the examination being to ascertain which general idea of quality is appropriate to the particular object examined.

"Here he attributes to an animal whose nature he does not fully understand, his own process of thought, and this appears to me to be a constant source of error in the investigation of animal psychology. That brutes possess self-consciousness, introspection, imagination, abstract thought, cannot, I think, be proved. The fact that animals possess faculties differing from those of man is an insuperable obstacle to a perfect analysis of their intelligences.

"Name these faculties as you please, call them 'inherited habit,' 'inherited memory,' it is perfectly certain that man does not possess them."

Now, far from it being "perfectly certain" that animals possess mental faculties differing in kind from our own, it seems to ine that, if we except the so-called "homing instinct" as a faculty about which as yet we know very little, it is "perfectly certain " that there is no other faculty presented by brutes which is not also presented by man. It is the converse proposition that is more difficult to combat-viz., that man possesses faculties of mind which appear at first sight to differ in kind from anything that is presented by animals. Therefore, while $\mathrm{I}$ should deem it almost superfluous to "prove" that man possesses "instincts" or "inherited habits" in common with animals, I have never attempted to "prove" that animals possess "self-consciousness" or "introspection" in common with man. Indeed, if Mr. Barclay will again read my article in NATURE, he will see that I expressly state my belief that these, the highest faculties of mind, may be, as the theory of evolution would lead us to expect they ought to be, confined to the highest product of psychological development.

As regards the illustration to which Mr. Barclay objects, I may observe that I selected it for the express purpose of disarming the criticism which he advances. Had I chosen for an illustration some "general idea of quality" more abstract than that of "good for eating or bad for eating," I could better have understood a critic accusing me of attributing to animals my "own process of thought" in the regions of self-conscious introspection. But seeing that $I$ do not myself require or perform any process of introspective thought in order to reject a rotten egg or to regale myself on good roast beef, $I$ cannot understand why I should not attribute to an animal precisely the same general ideas of "good for eating and bad for eating" that in my own case I know to be the causes of my acting precisely as I see animals act. The truth is that in speaking of general or abstract ideas we are not careful enough to discriminate between those simple ideas of quality which spring from mere sensuous associations, and those more elaborated ideas which spring from the more complex associations that are supplied by "mental reflection." But although it is of importance to remember that there is thus a great distinction between these two orders of abstract ideas, it is of no less importance to remember that both orders belong to the same class-all such ideas having reference to quality as abstracted from particular objects of perception, and the only difference between those of the one order and those of the other consisting in the higher degree of elabora tion which is supplied to our abstractions by the power of thinking about our thoughts. On the whole, therefore, I maintain that it can be "proved" that animals "possess abstract thought" of the inferior order which I have explained, and the phenomena of dreaming which is presented by several animals would seem sufficient proof that some animals, at least, possess a tolerably well-developed "imagination."

GEORGE J. ROMANES

I HAVE been reading with great interest the letters and discussions lately published in NATURE, on intellect in brutes, However, in none of them have I found any notice of a dog recognising a painted likeness of his master or any member of the family. I have seen, in other publications on this subject, that "this is one of the things a dog has never been known to do." During my residence in Cornwall I had a most intelligent and faithful dog for fifteen years. I had him when a month old. His mother was a beautiful liver-coloured spaniel, rather large; his father a black Newfoundland; my dog took after him in colour and shape.

In I843 a young and self-taught artist asked me to allow him to paint my likeness in oil colours, and I consented. His strdio was in the next town, three miles distant, and as often as required I went over; $I$, however, did not take my dog with me. It was done in Kit-cat size; and he succeeded so well in the likeness and artistic work, that when exhibited at the annual meeting of the Polytechnic Society at Falmouth, a medal was awarded to it, and, as well, it was " highly commended." Not only this, it brought him into notice and gained him lots of employment. The artist was so grateful for my attention that he presented me with the painting, and I still have it. When it was brought to my house, my old dog was present with the family at the "unveiling;" nothing was said to him nor invitation given him to notice it. We saw that his gaze was steadily fixed on it, and he soon became excited, and whined, and tried to lick and scratch it, and was so much taken up with it that we-although so well knowing his intelligence-were all quite surprised; in fact, could scarcely believe that he should know it was my likeness. We, however, had sufficient proof after it was hung up in our parlour; the room was rather low, and under the picture stood a chair; the door was left open without any thought about the dog; he, however, soon found it out, when a low whining and scratching was heard by the family, and on search being made, he was in the chair trying to get at the picture. After this I put it up higher, so as to prevent it being injured by him. This did not prevent him from paying attention to it, for whenever I was away from home, whether for a short or long time-sometimes for several days-he spent most of his time gazing on it, and as it appeared to give him comfort the door was always left open for him. When I was long away he made a low whining, as if to draw attention to it. This lasted for years, in fact as long as he lived, and was able to see it. I have never kept a dog since he died, I dare not-his loss so much affected me. I might tell of many of his wonderful actions; he could do most of such things as are related of other dogs. I am now only anxious to notice this recognition of my likeness, from never having heard of another such fact being recorded of any other dog.

Edinburgh

Chas. W. Peach

A CASE somewhat similar to that mentioned by Dr. Frost, of a cat scattering crumbs, occurred here within my own knowledge.

During the recent severe winter a friend was in the habit of throwing crumbs for birds outside his bedroom window. The family have a fine black cat, which, seeing that the crumbs brought birds, would occasionally hide herself behind some shrubs, and when the bircls came for their breakfast, would pounce out upon them with varying success. The crumbs had been laid out as usual, one afternoon, but left untouched, and during the night a slight fall of snow occurred. On looking out next morning my friend observed Puss busily engaged scratching away the snow. Curious to learn what she sought, he waited, and saw her take the crumbs up from the cleared space and lay them one after another on the snow. After doing this she retired behind the shrubs to wait further developments. This was repeated on two other occasions, until finally they were obliged to give up putting out crumb;, as Puss showed berself such a fatal enemy to the birds.

June 23 GREENOCK

\section{Aquarium Notes}

Marine Copepoda-The lump-sucker. - In the salt water tanks of the Edinburgh Aquarium at the present date may be seen an immense number of white specks flitting rapidly through the water, after the fashion of the familiar Cyclops and its neighbours in fresh streams. On subjecting these "tenants at will" of the tanks to microscopic serutiny, they are seen to belong to the Entomostracous division of the crustacea, and may in all probability be classified in the cyclops-faunily, as near kith and lin of the well-known "fresh-water fied." "The cephalothorax 